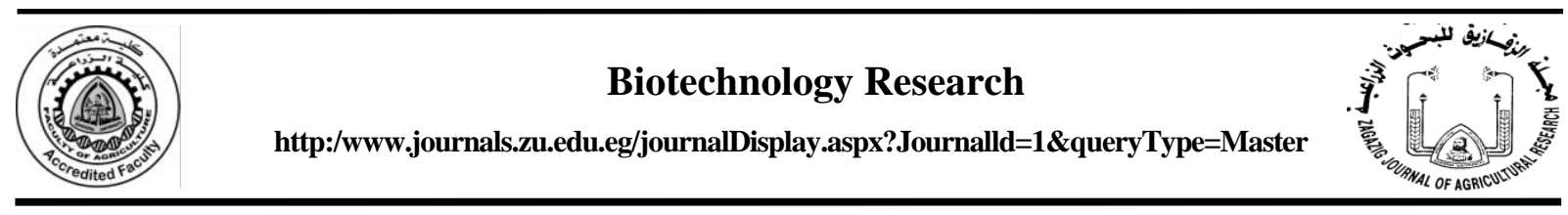

\title{
CHEMICAL COMPOSITION AND ANTIBACTERIAL ACTIVITY OF Codiaeum variegatum LEAVES
}

\author{
Noha E.S. Mohamed", R.A. El-Masry, A.E. Awad and H.A. Badr \\ Agric. Biochem. Dept., Fac. Agric., Zagazig Univ., Egypt
}

Received: 12/05/2019 ; Accepted: 12/06/2019

\begin{abstract}
Natural substances of botanical origin have been important in African traditional medical practice. They have been used for various illnesses such as infections. Infectious diseases caused by pathogenic bacteria affect many communities and the treatment was made difficult partly because of antibiotic resistant strains. Phytochemicals isolated from medicinal plants are known to be effective in treating bacterial infections. The antibacterial activities of the ethanol and water leaf extracts of Codiaeum variegatum were tested. Antibacterial effects of crude extracts were performed using modified Kirby-Bauer disc diffusion technique to determine the zone of inhibition. The extracts were tested for the antibacterial activities against Gram-positive bacteria (Bacillus subtilis) and Gramnegative bacteria (Serratia marcescens). The results demonstrated that both of ethanol and water leaf crude extracts of Codiaeum variegatum have shown strong zone of inhibition against Serratia marcescens $(20 \mathrm{~mm})$ and Bacillus subtilis $(12 \mathrm{~mm})$ compared to control. This medicinal plant could be developed into affordable and safe standardized herbal products and may serve as a source of new molecules for broad-spectrum antimicrobial agents.
\end{abstract}

Key words: Anti oxidant, water and ethanolic extract, antibacterial, total phenolic, total flavonoid.

\section{INTRODUCTION}

The World Health Organization reported that infectious diseases are responsible for one third of global mortality and that they still pose a major threat to public health in numerous countries (WHO, 2017). Their impact is more evident in developing countries due to the limited accessibility to medicines and the emergence of widespread drug resistance (Macedo et al., 2015). The increasing resistance of microorganisms to available antimicrobial agents is one of the major concerns for scientists and clinicians worldwide, and has become a global problem in the last years (Abad et al., 2012). Over the past decade, interest in the search for antimicrobial natural products has risen (Ahmad et al., 2006). From all possible sources of natural products, plants are considered as the most promising product (Macedo et al., 2015). Croton is the second most extensive genus of Euphorbiaceae with approximately 1250 species (Costa $\boldsymbol{e t}$ al.,

\footnotetext{
*Corresponding author: Tel. : +201147107644

E-mail address: nohagami193@gmail.com
}

2012). Currently, these species are known by presenting insecticidal, antimalarial, larvicidal (Dória et al., 2010), antimicrobial, antiulcerogenic (Almeida et al., 2013), molluscicidal, anthelminthic (Camurça et al., 2007), and anti-inflammatory (Nardi et al., 2003) activities.

Croton species are commonly used for treating diabetes, digestive disturbances, hypercholesterolemia, intestinal worms, fever, malaria and pain (Dória et al., 2010). Moreover, vasorelaxant effects have been attributed to some species of the Croton genus, which have been reported to contain alkaloids, terpenoids (diterpenes, pentacyclic triterpenoids and steroids), proanthocyanidins, flavonoids, and other phenolic compounds (Dória et al., 2010).

The aim of this work was to determine the antioxidant activity, total flavonoid, total phenolic, total alkaloid and anti bacterial activity of Codiaeum variegatum leaves. 


\section{MATERIALS AND METHODS}

\section{Plant Material}

The leaves of Codiaeum variegatum were collected from the farm of Faculty of Agriculture, Zagazig University. The plant was identified by botanical members of the Department of Botany, Faculty of Agriculture, Zagazig University, Egypt. The plant part were allowed to dry in a shady and well- aired place for 15 days, aerial parts of Codiaeum variegatum L., ware cut into small pieces, ground to fine powder using blender and kept for further investigations.

\section{Chemicals}

All solvents used throughout the present work were obtained from different companies. ABts, DPPH and Substrates were purchased from Sigma Chemical Co., St. Louis, USA.

\section{Methods}

\section{Preparation of ethanolic extracts}

The leaves of Codiaeum variegatum were extracted according to the method of Panovska et al. (2005) $50 \mathrm{~g}$ of dry powder were extracted with $500 \mathrm{ml}$ of $70 \%$ ethanol in a screw-capped flask and shaken at room temperature for $24 \mathrm{hr}$. The extract was centrifuged at 5500 r.p.m for 10 min while the residue was re-extracted under the same conditions twice and filtered through filter paper. The $70 \%$ ethanol extract were concentrated under reduced pressure, lyophilized to obtain powder, and stored at $-20^{\circ} \mathrm{C}$ until using for further study.

\section{Preparing aqueous extract}

About $500 \mathrm{~g}$ of the ground leaves of Croton were soaked in distilled water for seventy two hr., and the residue was separated. Finally the aqueous extract was lyophilized and the final yield was $50 \mathrm{~g}$. The resideu was kept in a clean vial and cooled in a refrigerator until use (Nwangwa and Ekhoye, 2013).

\section{Chemical composition of plant sample}

Determination of moisture, ash, crude fiber, crude protein and crude lipid were determined according to the method described in AOAC (2005).

\section{Total phenolic determination}

Total phenolic compounds were determined according to the method described by Ghasemzadeh et al. (2010).

\section{Determination of total flavonoids}

The total flavonoid compounds were determined according to the method described by Ahn $\boldsymbol{e t}$ al. (2007).

\section{Determination of total alkaloids}

The total alkaloids compounds were determined according to the method described by Adham (2015).

\section{Antioxidant Activity of Codiaeum variegatum}

\section{Free radical scavenging activity (RSA) DPPH assay}

The RSA of the ethanolic extract of Codiaeum variegatum leaves was assayed with 1, 1-diphenyl-2picrylhydrazyl (DPPH) radicals dissolved in ethanol. RSA and the presence of hydrogen donors in ethanolic extract was examined by reduction of DPPH in ethanol. An ethanolic solution of DPPH radicals was freshly prepared. The radical, in the absence of antioxidant compounds were stable for more than $2 \mathrm{hr}$., of normal kinetic assay. For evaluation, $100 \mu \mathrm{l}[80(\mu \mathrm{g} / \mathrm{ml}), 120(\mu \mathrm{g} / \mathrm{ml}), 150$ $(\mu \mathrm{g} / \mathrm{ml}), 200(\mu \mathrm{g} / \mathrm{ml})]$ ethanolic extract of studied plant was mixed with $5 \mathrm{ml}$ of ethanol solution of DPPH radicals and the mixtures were vortexed for $20 \mathrm{sec}$. at ambient temperature. Against a blank of pure ethanol without DPPH, the decrease in absorption at $515 \mathrm{~nm}$ was measured in 1-cm quartz cells, using a UV-260 visible recording spectrophotometer (Shimadzu, Kyoto, Japan). RSA toward DPPH radicals was estimated from the differences in absorbance of ethanol DPPH solution with or without sample (control) and the inhibition percentage was calculate according to Lee $\boldsymbol{e t}$ al. (2002), from the following equation:

Inhibition $(\%)=[($ absorbance of control absorbance of test sample) / absorbance of control] $\times 100$

\section{In vitro antimicrobial activity of resideu}

Antimicrobial activities of the tested samples were determined using a modified Kirby-Bauer disk diffusion method (Bauer et al., 1996). Plates inoculated with Gram (+) bacteria as Bacillus subtilis, ; Gram (-) bacteria as Serratia marcescens at $35-37^{\circ} \mathrm{C}$ for $24-48$ hours., and then the diameters of the inhibition zone were measured in millimetres (Bauer et al., 1996). Standard discs of tetracycline (antibacterial 
agent) served as positive control for antimicrobial activity but filter discs impregnated with $10 \mu \mathrm{l}$ of solvent (distilled water and Ethanol 70\%) were used as a negative control.

\section{RESULTS AND DISCUSSION}

\section{Proximate Composition of Codiaeum variegatum leaves}

The analyses of Codiaeum variegatum leaves content are recorded in Table 1. Results shoed that ash, crude protein, crude fat, crude fiber, carbohydrate and moisture valued $14.50 \%$, $15.56 \%, 4.68 \%, 20.70 \%, 43.71 \%$ and $14.60 \%$, respectively. Obtained results showed that the plant contained a considerable high amounts of ash, protein, fat, fiber and carbohydrate. These rustls are in harmmony with those obtemined by Babatunde et al. (2017) who stated that Codiaeum variegatum leaves contained crude ash $(12.58 \%)$, crude fat $(6.52 \%)$, crude fiber $(19.52 \%)$ and carbohydrate $(57.77 \%)$.

\section{The Total of Active Components in Codiaeum variegatum Leaves}

Rice-Evans et al. (1996) and Mattei et al. (1998) reported that phenolic compounds have at least one aromatic ring which can carry the hydroxyl groups which can known as reducing agents. The natural antioxidants such as phenolics and flavonoids compounds have wide spectrum pharmacological effects like antibacterial, anti-allergic, neuroprotective activities, antiinflammatory and anticancer, also protect plants from the attack of pathogenic microbial. (Mohd et al., 2012) reviewed that the Croton plant is a great source of bioactive compounds like flavonoid and phenolic. Therefore, the total flavonoid and phenolic in the Croton plant are very important to discover the effect of Croton extract. Veni et al. (2015) reported that the Codiaeum variegatum is an ornamental plant and also known for its medicinal properties. The medicinal properties of plants are due to the phytochemicals. These phytochemicals are the secondary metabolites which are produced in adiquate quantity under stressed conditions, which allows the plant caused tolerance against adverse environmental factors. Dietary intake of these phytochemicals may promote health benefits, protecting against chronic degenerative disorders, such as cancer, cardiovascular and neurodegenerative diseases. This investigation shoewd that the phenolic contents was (65 mgGAE/ g), flavonoid was $27 \mathrm{mg} \mathrm{QE} / \mathrm{g}$. and total alkaloid was $3.71 \mathrm{~g} / 100 \mathrm{~g}$ ) Veni et al. (2015) reported that the Codiaeum variegatum quantitative estimation revealed that alkaloid is in between the range of (4.66 - 10.2\%), flavonoids (33.1-37.63\%), saponins (11.36 - 13.76\%), phenolics (35.43-39.76\%), tannins (10.5-15.32\%), terpenoids (27.56-30.3\%), also they found that the plant is rich in flavonoids, phenols and terpenoids. The Codiaeum variegatum is known to have medicinal properties like anticancer and anti-inflammatory properties. This study revealed the presence of medicinal active constituents of Codiaeum variegatum like flavonoids, phenols and terpenoids which are rich and may be contributing in providing the medicinal properties to the plant. The inflammation is mainly caused by cyclooxygenase and lipooxygenase pathway. Phenolic compounds were shown to inhibit the cyclooxygenase and lipooxygenase pathway (Ferrandiz et al., 1990; Ferrandiz and Alcaraz, 1991; Laughton et al., 1991). Flavonoids are found to inhibit Ornithine decarboxylase enzyme, it is rate-limiting enzyme in polyamine biosynthesis, which has been correlated with the rate of DNA synthesis and cell proliferation in several tissues, hence inhibiting cell proliferation (Makita et al., 1996; Tanaka et al., 1997a; Tanaka et al., 1997b). Flavonoids inhibit growth of microorganism by depolarizing membrane, inhibiting DNA, RNA and protein synthesis (Dzoyem et al., 2013). Study of flavonoids, phenols and terpenoids from this plant may help to exploit more of the medicinal properties of Codiaeum variegatum leaves (Table 2).

\section{Radical Scavenging Activity (RSA) of Codiaeum variegatum leaves Extract}

Many studies in the last ten years interested in the theory of free radical disease causation, especially in certain forms of cancer and vascular diseases. Because of the developments in the free radical field have guided us to the consideration on dietary agents, the natural antioxidant (especially vitamins E, A, and C), in a possible prophylactic and the role of the disease process. A free radical is a chemical 
Table 1. Percentage of the proximate compositions of Codiaeum variegatum leaves

\begin{tabular}{lc}
\hline Parameter & Croton \\
\hline Moisture (\%) & $14.6 \%(\mathrm{fw})$ \\
Crude proteins (\%) & $15.56 \%(\mathrm{Dw})$ \\
Crude fats (\%) & $4.68 \%(\mathrm{Dw})$ \\
Crude fibers (\%) & $20.7 \%(\mathrm{Dw})$ \\
Carbohydrates (\%) & $43.71 \%(\mathrm{Dw})$ \\
Ash (\%) & $14.5 \%(\mathrm{Dw})$ \\
\hline
\end{tabular}

Fw $=$ fresh weight $\quad$ Dw $=$ dry weight

Table 2. The total phenolic, total flavonoid and total alkaloid contents of Codiaeum variegatum Leaves

\begin{tabular}{cccc}
\hline Plants extract & $\begin{array}{c}\text { Total phenolic content } \\
(\mathbf{m g ~ G A E} / \mathrm{g} \text { sample DW) }\end{array}$ & $\begin{array}{c}\text { Total flavonoid content } \\
(\mathbf{m g} \text { quercetin/g sample DW) }\end{array}$ & $\begin{array}{c}\text { Total Alkaloid } \\
(\mathbf{g} / \mathbf{1 0 0} \mathbf{g})\end{array}$ \\
\hline Croton & 65.551 & 27.924 & 3.017 \\
\hline
\end{tabular}

species that has unpaired electrons Pryor $\boldsymbol{e t}$ al. (2006). These electrons, which made free radicals are very reactive and take section in chemical reactions with other components in cell such as proteins, complex carbohydrates, nucleic acids and lipids in the body (Kohen and Nyska, 2002). In the biological systems, free radicals are referred to reactive oxygen species (ROS), as the most biologically significant free radicals. ROS produced in cells include hydroxyl radical $\left(\mathrm{OH}^{*}\right)$, hydrogen peroxide $\left(\mathrm{H}_{2} \mathrm{O}_{2}\right)$, and superoxide anion $\left(\mathrm{O}_{2}\right)$ Pryor et al. (2006).

Table 3 show the antioxidant activity of $C$. variegatum leaves. All the samples analysed showed an increase in antioxidant activity with increasing concentrations, thus exhibiting a concentration dependent pattern of free radical scavenging ability. The extract of $C$. variegatum recorded a stronge antioxidant activity. Members of the Euphorbiaceae plant family possess strong antioxidant activities which are greatly associated with the presence of phenolic compounds (Shahwar et al., 2010).

For instance, analysis of the leaf extract of $C$. variegatum cv spiral and royal-like by HPLCDAD showed that ellagic acid, a phenolic compound may be responsible for its antioxidant activity (Saffoon et al., 2014).

\section{Antimicrobial Activity}

The intensive use of antibiotics is often followed by the presence of resistant strains of microorganisms. In view of the resistance of bacteria to drugs, the search for natural compounds having antibacterial activity is an urgent one in order to cope with the harmful effects of these microorganisms. For these reasons, accordingly, in this research two extracts i.e.by ethyl alcohol and water were tested against different microorganisms Grampositive Bacillus subtilis $\left(\mathrm{G}^{+}\right)$and Gram negative bacteria.; Serratia marcescens $\left(\mathrm{G}^{-}\right)$. Inhibition zones are recorded as shown in Tables 4,5 . Control was in the same conditions. It was observed that control (DMSO) did not produce any inhibition zones. It is showed that all extracts gave rise to concentration dependent inhibition zones in the two types of bacteria (positive and negative Gram).

The results of the present study showed that the leaves water extract of Codiaeum variegatum inhibited the growth of tested isolate strongly; this may be due to presence of the phytochemical groups as mentioned in Table 2 . 
Zagazig J. Agric. Res., Vol. 46 No. (4) 2019

Table 3. DPPH scavenging activity of Codiaeum variegatum leaves extract

\begin{tabular}{lcccc}
\hline Plant extract concentration & $\mathbf{8 0}(\boldsymbol{\mu g} / \mathbf{m l})$ & $\mathbf{1 2 0}(\boldsymbol{\mu g} / \mathbf{m l})$ & $\mathbf{1 5 0}(\boldsymbol{\mu g} / \mathbf{m l})$ & $\mathbf{2 0 0}(\boldsymbol{\mu g} / \mathbf{m l})$ \\
\hline DPPH $(\%)$ & $50.45 \%$ & $52.86 \%$ & $55.13 \%$ & $56.47 \%$ \\
\hline
\end{tabular}

Table 4. Effect of ethanolic extract resideu on the diameter inhibition zone (mm) of microorganisms

\begin{tabular}{ccc}
\hline Concentration & \multicolumn{2}{c}{ Inhibition zone diameter $(\mathbf{m m} / \mathbf{m g}$ sample) } \\
\cline { 2 - 3 } & St.marcescens $(\mathbf{G}-)$ & B. subtilis $(\mathbf{G}+)$ \\
\hline Control : DMSO & NI & NI \\
1- (120mg/ml) & 19 & 12 \\
2- (60mg/ml) & 17 & 10 \\
3- (30mg/ml) & 8 & 13 \\
4- (15mg/ml) & 13 & 7 \\
\hline
\end{tabular}

Table 5. Effect of water extract resideu on the diameter inhibition zone ( $\mathrm{mm})$ of microorganisms

\begin{tabular}{ccc}
\hline Sample & \multicolumn{2}{c}{ Inhibition zone diameter (mm/mg sample) } \\
\cline { 2 - 3 } & St.marcescens $(\mathbf{G}-)$ & B.subtilis $(\mathbf{G}+)$ \\
\hline Control : DMSO & NI & NI \\
1- $(\mathbf{8 0 0} \mathbf{~} \mathbf{m} / \mathbf{m l})$ & 20 & 9 \\
2- $(\mathbf{4 0 0} \mathbf{~} \mathbf{g} / \mathbf{m l})$ & 19 & 8 \\
3- $(\mathbf{2 0 0} \mathbf{~ g / m l )}$ & 19 & 8 \\
4- $(\mathbf{1 0 0} \mathbf{~} \mathbf{g} / \mathbf{m l})$ & 10 & 7 \\
\hline
\end{tabular}

According to the findings, Serratia marcescens was found to be more sensitive to the extract than Bacillus subtilis. This result are in the same line with Aylate et al. (2017) who stated that extracts from croton plant showed stronger antibacterial activity also stated that the extract has shown the lowest inhibition zone $(9.25 \pm 0.54 \mathrm{~mm})$ against $E$. coli and the highest inhibition zone $(21.63 \pm 0.02)$ was seen against $S$. aureus. In addition, the extract was significantly better than the effect of tetracycline against $S$. aureus. Relatively higher number of organs with lesion and death of mice during the trial was registered in experimental groups, infected with $E$ coli than $S$. aureus infected ones, both treated with the plant extract. These findings present scientific evidences for the use of this plant as a remedy against disease caused by $S$. aureus and E. coli pathogens.

\section{Conclusion and Recommendations}

The results and discussion of this study clearly indicated that Codiaeum variegatum leaves have ample potential to inhibit two human and animal pathogenic bacteria as seen from its strong inhibition against tested organisms. Codiaeum variegatum shows much promise in the development of phyto-medicine 
having antimicrobial properties and the drug derived from Codiaeum variegatum may have the possibility of alternative medicinal source because of their antibacterial activity. This study also indicated that ethanol and water extract of this plant has highest capability to antibacterial activity against Serratia marcescens and Bacillus subtilis. In general, it can be concluded that ethanol and water extracts of Codiaeum variegatum is a strong inhibitor for bacterial growth. Therefore, it is recommended to identify the active ingredients of the antibacterial agent and obtaining chemotherapist agent in different drug formulations therefore be used for enteric and systemic infections caused by Serratia marcescens and Bacillus subtilis.

\section{REFERENCES}

Abad, M.J., L.M. Beyoda, L. Apaza and P. Bermejo (2012). Anti-infective flavonoids: an overview. In: Brahmachari, G. (Ed.), Bioactive Natural Products: Opportunities and Challenges in Med. Chem. World Sci., Singapore, 443-474.

Adham, A.N. (2015). Comparative extraction methods, phytochemical constituents, fluorescence analysis and HPLC validation of rosmarinc acid content in Mentha piperita, Mentha longifolia and Osimum basilicum. J. Pharmacognosy and Phytochem., 3 (6): 130139

Ahmad, I., F. Aqil and M. Owais (2006). Modern Phytomedicine: Turning Medicinal Plants into Drugs. John Wiley and Sons, Germany.

Ahn, M.R., S. Kumazawa, Y. Usui, J. Nakamura, M. Matsuka, F. Zhu and T. Nakayama (2007). Antioxidant activity and constituents of propolis collected in various areas of China. Food Chem., 101: 1383-1392.

Almeida, T.S., J.B.T. Rocha, F.F.G. Rodrigues, A.R. Campos and J.G.M. Costa (2013). Chemical composition, antibacterial and antibiotic modulatory effect of Croton campestres essential oils. Ind. Crops Prod., 44: 630-633.

AOAC (2005). Official Methods of Analysis of Assocation of Official Agriculture Chemists, Washington DC 17 Ed.
Aylate, A., M. Agize, D. Ekero, A. Kiros, G. Ayledo and K. Gendiche (2017). In-vitro and In-vivo Antibacterial Activities of Croton macrostachyus Methanol Extract against E. coli and S. aureus. Advan. Anim. and Vet. Sci., 5 (3): 107-114

Babatunde, E.E., A.F. Banji, O. Foluke, A.D. Ayandiran and F. Kotun (2017). Comparative study of leaf morphology, phytochemical, mineral and proximate analysis of Codiaeum variegatum (L.) A. Juss. (Malpighiales: Euphorbiaceae) and its stable mutant. Brazilian J. Biol. Sci., 4 (7): 25-34.

Bauer, A.W., W.M. Kirby, C. Sherris and M. Turck (1996). Antibiotic suscepyibility testing by a standardized single disk method, Ame. J. Clin. Pathol., 45: 493 - 496.

Camurça, V.A.L.F., C.M.L. Bevilaqua, S.M. Morais, M.V. Maciel, C.T.C. Costa, I.T.F. Macedo, L.M.B. Oliveira, R.R. Braga, R.A. Silva and L.S. Vieira (2007). Anthelmintic activity of Croton zehntneri and Lippia sidoides essential oils. Vet. Parasitol., 30: 288-294.

Costa, F.L.O., M.H.M. Silva, J.S. AlmeidaCortez, S.I. Silva and A.F.M. Oliveira (2012). Foliar cuticular n-alkane of some Croton species from Brazilian semiarid vegetation. Biochem. Syst. Ecol., 41: 13-15.

Dória, G.A.A., W.J. Silva, G.A. Carvalho, P.B. Alves and S.C.H. Cavalcanti (2010). A study of the larvicidal activity of two Croton species from northeastern Brazil against Aedes aegypti. Pharm. Biol., 48: 615-620.

Dzoyem, J.P., H. Hamamoto, B. Ngameni, B.T. Ngadjui and K. Sekimizu (2013). Antimicrobial action mechanism of flavonoids from Dorstenia species. Drug Discov. Ther., 7 (2): 66-72.

Ferrandiz, M.L. and M.J. Alcaraz (1991). Antiinflammatory activity and anhibition of archidonic acid metabolism by flavonoids. Agents Actions, $32: 283-288$.

Ferrandiz, M.L., A.G. Nair and M.J. Alcaraz (1990). Inhibition of sheep platelet arachidonate metaboilm by flavonoids from Spanish and Indian medicinal herbs. Pharmazie, 45: 206-208. 
Ghasemzadeh, A., H.Z.E. Jaafar and A. Rahmat (2010). Antioxidant activities, total phenolics and flavonoids content in two varieties of Malaysia young ginger (Zingiber officinale Roscoe). Molec., 15 (6): 4324- 4333.

Kohen, R. and A. Nyska (2002). Oxidation of biological systems: oxidative stress phenomena, antioxidants, redox reactions, and methods for their quantification. Toxicol. Pathol., 30 (6): 620- 650 .

Laughton, M.J., P.J. Evans, M.A. Moroney, J.R. Hoult and B. Halliwell (1991). Inhibition of mammalian 5-lipoxygenase and cyclooxygenase by flavonoids and phenolic dietary additives. Relationship to antioxidant activity and to iron-reducing ability. Biochem. Pharmacol., 42: $1673-1681$

Lee, J.C., H.R. Kim and Y.S. Jange (2002). Antioxidant property of an ethanol extract of the stem of Opuntia ficus indica var. Saboten. J. Agric. Food Chem., 50 : 64906496.

Macedo, M.B., S. Clais, E. Lanckacker, L. Maes, E.S. Lima and P. Cos (2015). AntiInfective Agents: the Example of Antibacterial Drug Leads. Ethnopharmacology In: Heinrich, M., Jäger, A.K. (Eds.), John Wiley Sons Ltd., 109-122.

Makita, H., T. Tanaka, H. Fujitsuka, N. Tatematsu, K. Satoh, A. Hara and H. Mori (1996). Chemoprevention of 4-nitroquinoline 1-oxide-induced rat oral carcinogenesis by the dietary flavonoids chalcone, 2hydroxychalcone, and quercetin. Cancer Res; 56: 4904-4909.

Mattei, R., R.F. Dias, F.B. Espinola, E.A. Carlini and S.B.M. Barros (1998). Guarana (Paullinia cupana): Toxic behavioral effects in laboratory animals and antioxidant activity in vitro. J. Ethnopharmacol., 60: 111-116.

Mohd, A.N., H.V. Annegowda, S.M. Mansor, S. Ismail, S. Ramanathan and M.N. Mordi (2012). Phytochemical screening, antioxidant and analgesic activities of Croton argyratus ethanolic extracts. J. Med. Plants Res., 6 (21): 3724-3731.

Nardi, G.M., R.S. Felippi, S. Dalbó, J.M. Siqueira-Junior, D.C. Arruda, F. Delle
Monache, A.K. Timbola, M.G. Pizzolatti, K. Ckless and R.M. Ribeiro-do-Valle (2003). Antiinflammatory and antioxidant effects of Croton celtidifolius bark. Phytomedicine, 10: 2-3.

Nwangwa, E.K. and E.I. Ekhoye (2013). Antihyperlipidemic activity of aqueous extract of Carica papaya seed in albino rats fed with high fat diet. Current Trends in Technol. and Sci., 2 (1): 262-266.

Panovska, K.T., S. Kulevanova, M. Stefov (2005). In vitro antioxidant activity of some Teucrium Species (Lamiaceae) Acta Pharm., 55 : 207214.

Pryor, W.A., K.N. Houk, C.S. Foote, J.M. Fukuto, L.J. Ignarro, G.L. Squadrito and K.J.A. Davies (2006). Free radical biology and medicine: it's a gas, man! Ame. J. Physiol. Regul. Integr. Comp Physiol., 291 (3): 491-511.

Rice-Evans, C.A., N.M. Miller and G. Paganda (1996). Structure-antioxidant activity relationships of flavonoids and phenolic acids. Free Radic. Biol. Med., 20: 933-956.

Saffoon, N., R. Uddin, N. Subhan, H. Hossain, M. Reza and A. Alam (2014). In vitro antioxidant activity and HPLC-DAD system based phenolic content analysis of Codiaeum variegatum found in Bangladesh. Adv. Pharmaceutical Bulletin., 4 (2): 533-41.

Shahwar, D., S. Rehman, N. Ahmad, S. Ullah and M. Raza (2010): Antioxidant activities of the selected plants from the family Euphorbiaceae, Lauraceae, Malvaceae and Balsaminaceae. Afr. J. Biotechnol., 9 (7): 1086-96.

Tanaka, T., H. Makita, K. Kawabata, H. Mori, M. Kakumoto, K. Satoh, A. Hara, T. Sumida, T. Tanaka and H. Ogawa (1997a). Chemoprevention of azoxymethane-induced rat colon carcinogenesis by the naturally occurring flavonoids, diosmin and hesperidin. Carcinogenesis, 18:957-965.

Tanaka, T., H. Makita, M. Ohnishi, H. Mori, K. Satoh, A. Hara, T. Sumida, K. Fukutani, T. Tanaka and H. Ogawa (1997b). Chemoprevention of 4-nitroquinoline 1oxide-induced oral carcinogenesis in rats by flavonoids diosmin and hesperidin, each alone and in combination. Cancer Res., 57: 246-252. 
Veni, S.R.B. and M.C. Gayatri (2015). WHO (2017). World Health Organization. Fact Phytochemical profile of Codiaeum Sheet: the Top 10 Causes of Death. http:// variegatum (L.) Bl, Int. J. Pharmacol. Pharm. www.who.int/mediacentre/factsheets/fs310/e Sci., 2 (3): 22-31. $\mathrm{n} /$, Accessed date.

Codiaeum variegatum التركيب الكيميائي والتأثير المضاد للبكتريا لأوراق نبات الكروتون

$$
\text { نهي السيد صلاح محمد - رجب عبد الفتاح المصري ـ أحمد السيد عوض ـ هيثم علي بلر الكيمياء الحيوية ـ كلية الزر اعة ـ جامعة الزقازيق ـ مصر }
$$

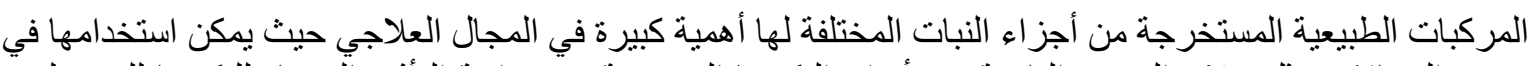

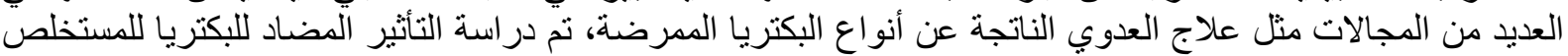

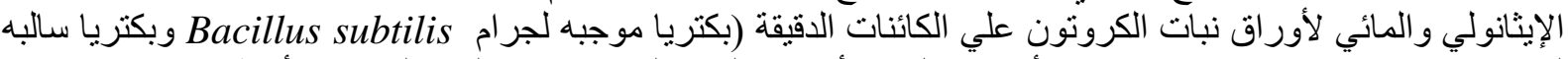

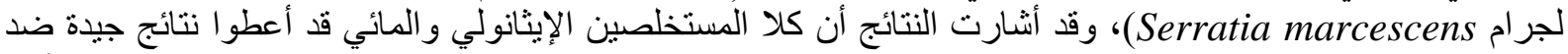

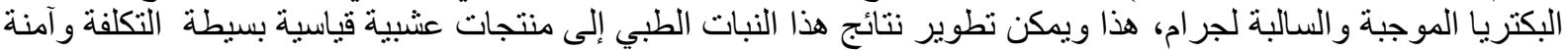

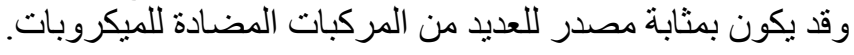

